\title{
PEMBELAJARAN PENDIDIKAN PANCASILA DI FAKULTAS AGAMA ISLAM UNIVERSITAS MUHAMMADIYAH GRESIK
}

\author{
Man Arfa Ladamay \\ Universitas Muhammadiyah Gresik
}

\begin{abstract}
Abstrak
Pada dasarnya permasalahan yang terjadi ialah keberadaan Pancasila sebagai dasar Negara yang sekaligus menjadi landasan nilai filosofi, ideologi, moral, etika dan pandangan hidup berbangsa serta bernegara, dewasa ini semakin terkikis oleh nilai kebudayaan asing. Usaha yang dilakukan untuk mengantisipasi persoalan tersebut dengan adanay penerapan pendidikan karakter dari pemerintah. Hasilnya menunjukkan bahwa dengan penegasan karakter bangsa yaitu Pancasila kepada peserta didik mampu untuk mencegah masuknya budaya Asing terutama budaya yang tidak sesuai dengan budaya asli bangsa Indonesia yang menjunjung tinggi peradaban moralitas.
\end{abstract}

Kata Kunci: pembelajaran, pendidikan, pancasila 


\section{PENDAHULUAN}

$\mathrm{K}$

beradaan Pancasila sebagai dasar Negara yang sekaligus menjadi landasan nilai filosofi, ideologi, moral, etika dan pandangan hidup berbangsa

serta bernegara, dewasa ini semakin terkikis oleh nilai kebudayaan asing. Fenomena tersebut begitu kental terlihat pada pola pikir dan gaya hidup sebagain generasi muda anak negeri ini yang cenderung berpenanmpilan mengikuti cara hidup budaya Barat yang sekuler, yang cinta dunia secara berlebihan dan meninggalkan nilai budaya bangsa sendiri yang religius. Kondisi demikian sudah dikuatirkan oleh M. Natsir tentang "adanya penyakit bangsa Indonesia, termasuk umat Islam, yaitu cinta berlebihan kepada dunia."1

Pergeseran orientasi kehidupan yang menjauhi nilai Pancasila dikuatirkan menyebabkan bangsa Indonesia dapat kehilangan karakter diri, yang akan berdampak punahnya identitas diri sebagai bangsa. Sebagaimana dimaklumi bahwa keberadaan Pancasila sebagai dasar Negara, falsafah hidup bangsa dan ideologi serta etika berkepribadian dalam bermasyarakat, berbangsa dan bernegara bersumber dari nilai ajaran agama, nilai kebudayaan dan nilai adat istiadat yang hidup dan tumbuh serta berkembang sejalan dengan perubahan dan perkembangan kesadaran bangsa Indonesia secara komprehensif. Oleh sebab itu, tidaklah diragukan lagi bahwa keberadaan nilai Pancasila akan bertentangan dengan sistem nilai agama, kebudayaan dan adat istiadat yang ada dalam masyarakat Indonesia.

Namun demikian proses pertumbuhan dan perubahan sosial dari kehidupan masyarakat Indonesia sebagai bangsa yang terbuka, tidak dapat dipisahkan dari adanya issue politik new kolonialisme yang namanya "Era Globalisasi" dengan semua konsekuensinya berupa perubahan dan perkembangam masyarakat dunia yang hidup mengglobal. Fenomena tersebut ditandai adanya perkembangan teknologi komunikasi modern yang mengakibatkan tidak adanya sekat kehidupan antara umat manusia diberbagai belahan dunia ini.

Kondisi kehidupan masyarakat yang kian terbuka dewasa ini sebagai konsekuensi dari derasnya arus informasi akibat globalisasi, berdampak pada eksistensi nilai kebudayaan dan keyakinan masyarakat dari suatu bangsa, disebabkan mudahnya di-pengaruhi oleh masuknya nilai budaya asing (Budaya Barat) yang berorientasi pada kebebasan dan materialisme yang kian mendominasi peradaban umat manusia di muka bumi. Dimana mereka menge-depankan karakter dengan prinsip "Tujuan menghalalkan cara". Kondisi demikian dapat mempengaruhi ketahanan nilai-nilai keyakinan yang menjadi kepribadian masyarakat suatu bangsa, tidak terkecuali bangsa Indonesia yang memang masih labil, sehingga mengakibatkan bergesernya ka-rakter masyarakat bangsa tersebut dari nilai kepribadian yang seharusnya menjadi identitas diri setiap warga masyarakatnya, menjadi masyarakat yang asing bagi dirinya sendiri secara komprehensif.

Berkenan dengan derasnya arus globalisasi yang menggerus nilai karakter bangsa Indonesia yang tampak jelas saat ini, konsekuensinya menjadi sangat penting bagi bangsa ini untuk membangun dan membina karakter generasi muda khususnya mahasiswa, agar tidak semakin terpuruk dan terjebak pada pola pikir dan tindakan 
tergolong dalam ideologi bersifat radikalisme yang menggejala dikalangan mereka. Keadaan yang mencerminkan rapuhnya karakter generasi penerus bangsa sangat memprihatinkan semua pihak mulai dari orangtua, pendidik hingga para pemimpin nasional bangsa Indonesia. Menyikapi kondisi karakter bangsa yang tidak menggembirakan presiden Susilo Bambang Yudoyono kala itu menyatakan bahwa bahwa "Pembangunan watak (Character building) amat penting. Kita ingin membangun manusia Indonesia yang berahklak, berbudi pekerti, dan berperilaku baik.

Bangsa kita ingin pula memiliki peradaban yang unggul dan mulia. Peradaban demikian dapat kita capai apabila masyarakat kita juga masyarakat yang baik $(\text { good society })^{2}$ Komitmen yang senada berkenaan pentingnya pendidikan karakter anak bangsa juga ditunjukan presiden Joko Widodo yang mencanangkan kebijakan yang popular dengan istilah "Revolusi Mental merupakan suatu gerakan seluruh masyarakat (pemerintah dan rakyat) dengan cara yang cepat untuk mengangkat kembali nilai-nilai strategis yang diperlukan oleh Bangsa dan Negara untuk mampu menciptakan ketertiban dan kesejahteraan arakyat sehingga dapat memenangkan persaingan di era globalisasi.",3

Keinginan luhur penguasa dan warga negara untuk menjadi bangsa berkarakter baik, bukanlah sesuatu yang bersifat utopis belaka, namun harus menjadi komitmen bersama dan ditransformasikan sebagai pola pikir, sikap dan perilaku bersama seluruh lapisan komponen masyarakat. Apabila kehendak membangun karakter tidak dimanifestasikan ke dalam kebijakan nasional dan hanya sekedar menjadi slogan kosong penguasa, bisa diprediksi kehendak mulia tersebut akan sia-sia belaka.

Menghadapi kondisi karakter masyarakat bangsa yang kian memprihatinkan, mendorong pemerintah terutama kementrian pendidikan dan kebudayaan untuk mengambil kebijakan strategis merealisasi pendidikan karakter di semua level pendidikan dari tingkat pendidikan dasar hingga perguruan tinggi. Komitmen tersebut sebagaimana dideklarasikan ketika M. Nuh Mendiknas dihadapan para rektor seluruh Indonesia tentang "Gerakan Anti Mencontek dan Anti Plagiat. Dijelaskannya bahwa budaya mencontek itu merupakan ekspresi dari sebuah pelanggaran. Budaya tersebut kalau larinya ke negatif harus kita tindak tegas." 4

Fenomena adanya budaya mencontek dan plagiat yang mentradisi di dunia pendidikan mulai dari tingkat sekolah dasar hingga perguruan tinggi dewasa ini, merupakan indikator lemahnya komitmen berlaku jujur dan berkemauan baik untuk bersikap disiplin dan adil serta bertanggung jawab pada diri sendiri dan kebenaran ilmiah, baik secara intelektual, emosional maupun spiritual. Nuansa kehidupan dunia pendidikan khususnya yang disinyalir tidak semakin dekat pada terbinanya peserta didik dengan nilai-nilai karakter baik/positif, yang bersumber dari falsafah dan etika serta kepribadian bangsa yang berdasarkan Pancasila, hendaknya ditinggalkan dan kembali untuk berfokus pada nilai Pancasila dalam menjalankan pendidikan karakter diseluruh jenjang pendidikan yang ada di Negara Indonesia.

Sebagaimana dimaklumi, bahwa Pancasila dirumuskan untuk bangsa Indonesia 
yang diproklamirkan pada tahun 1945, namun disadari jauh sebelum kemerdekan masyarakat Indonesia yang bersifat majemuk/bhineka telah memiliki ideologi yang beragam sebagai keyakinan dalam mengatur dan mengendalikan kehidupan kolektifnya. Konsekuensi adanya kera-gaman ideologi yang hidup dan mengayomi kehidupan masyarakat, termasuk para maha-siswa, baik bersumber dari ajaran agama Islam, Kristen, Hindu, Budha dan Kong Fu Cu. Mengakibat kehadiran Pancasila sebagai ideologi bangsa sejak kita merdeka tidak serta merta dapat menggeserkan ideologi lama yang telah mendarah daging dalam kehidupan social warga Negara Indonesia. Walaupun disadari tidak ada pertentangan antara Pancasila dengan paham ideologi yang telah ada dalam masyarakat, namun keberadaan nilai agama, kebudayaan dan adat istiadat sebagai ideologi misalnya, jika tidak disosialisasi secara bijak dapat menimbulkan kontradiksi nilai yang berdampak pada penolakan dan timbulnya karakter buruk berupa radikalisme ideologi.

Dunia kampus termasuk dilingkungan perguruan tinggi Islam, mulai terjangkiti penyakit atau virus pemikiran sempit yang hanya berfokus pada ideologinya dan menutup diri dari pandangan pahan pemikiran lain yang ada dan berkembang di sekitarnya. Kondisi demikian sebagaimana dikemukakan oleh Nuim Hidayat bahwa "Bila kita cermati, saat ini para aktivis mahasiswa Islam terkotak-kotak dan mayoritas cenderung fanatik terhadap organisasi atau gerakannya."5 Kondisi kehidupan mahasiswa yang terkotak-kotak dan terjebak pada sentiment berpikir sekterian akan melahirkan mahasiswa bermental primodialisme dan berjiwa fanatic golongan yang dapat mengakibatkan hancurnya karakter kepribadian mahasiswa sebagai aset bangsa Indonesia.

Pemerintah dalam kebijakan pendidikan nasional telah menyelenggarakan pendidikan karakter bagi generasi bangsa mulai jenjang sekolah dasar hingga perguruan tinggi, yang diimplementasikan dalam pengajaran mata kuliah pengembangan kepribadian khusus untuk mahasiswa di perguruan tinggi. Pendidikan Pancasila adalah satu diantara mata kuliah tersebut, disamping itu terdapat mata kuliah pendidikan Agama, pendidikan Kewarganegaraan dan pendidikan Bahasa Indonesia. Berkaitan dengan pembinaan karakter mahasiswa Fakultas Agama Islam Universitas Muhammadiyah Gresik, penelitian ini berminat meneliti "Peranan Pendidikan Pancasila dalam Pembinaan Karakter Mahasiswa di Fakultas Agama Islam Universitas Muhammadiyah Gresik.

Adapun perumusan masalah dalam penelitian ini adalah 1) bagaimana proses pembelajaran pendidikan Pancasila di Fakultas Agama Islam Universitas Muhammadiyah Gresik?, 2) bagaimana kondisi karakter mahasiswa Fakultas Agama Islam Universitas Muhammadiyah Gresik?, dan 3) bagaimana peranan pendidikan Pancasila dalam membina karakter mahasiswa Fakultas Agama Islam Universitas Muhammadiyah Gresik?.

\section{METODOLOGI}

Penelitian ini menerapkan jenis metode penelitian kualitatif, yang menurut Sugiyono ${ }^{6}$ diartikan sebagai metode penelitian yang berdasarkan pada filsafat postpositivisme, digunakan untuk meneliti pada kondisi obyek yang alamiah, (sebagai 
lawannya adalah eksperimen) dimana peneliti adalah sebagai instrumen kunci, pengambilan sampel sumber data dilakukan secara pusrposif dan snowbaal, teknik pengumpulan data dilakukan dengan trianggulasi (gabungan), analisis data bersifdat induktif/kualitatif, dan hasil penelitian kualitatif lebih menekankan makna dari pada generalisasi.

Penelitian ini membatasi lingkup pengkajiannya sesuai kemampuan peneliti, dalam penguasaan ilmu, pembiayaan dan target alokasi waktu yang tersedia, dengan memokuskan pembahasan mengenai peran pendidikan Pancasila dalam pembinaan karakter mahasiswa fakultas agama Islam yang berlokasi di Unmuh Gresik. Penentuan lokasi penelitian didasari pada pertimbangan bahwa kondisi mahasiswa sebagai sasaran penelitian mayoritas adalah berasal dari kalangan keluarga berlatar belakang sosial keagamaan yang tergolong taat. Dimana kondisi demikian terkadang mereka menjadi eksklusif terhadap nilai yang berasal dan pemikiran non agamanya. Berkaitan dengan kondisi tersebut menjadi sangat substansial bagi peneliti untuk menelaah peran pendidikan Pancasila dalam pembinaan karakter mahasiswa FAI, sehingga tidak terkontaminasi nilai dan pemikiran radikalisme.

Kualitas data dan informasi hanya dapat diperoleh apabila penentuan informan lebih terfokus pada individu dalam kelompok, sebagai figur yang memiliki keunggulan lebih mengetahui, memahami, dan merasa-kan sebagai bagian representatif yang dimaksud. Informan dalam penelitian ini diantaranya adalah Dosen dan mahasiswa Fakultas Agama Islam Unmuh Gresik..
Sesuai dengan fokus permasalahan penelitian, yang dijadikan sumber data dan teknik pengumpulan data adalah sebagai berikut: 1) data tentang Peran Pendidikan Pancasila sumber datanya adalah Ka. Prodi PAI, dosen dan mahasiswa serta dokumen yang berkaitan dengan mahasiswa FAI. Teknik pengumpulan datanya adalah observasi dan wawancara dan studi dokumentasi, dan 2) data tentang Pembinaan karakter mahasiswa, sumber datanya adalah Ka. Prodi, dosen dan para mahasiswa. Teknik pengumpulan datanya adalah observasi dan wawancara.

Berdasarkan tujuan penelitian, teknik pengumpulan data yang digunakan dalam penelitian ini adalah interview (wawancara), observasi, dan dokumentasi, atau gabungan ketiganya (trangulasi).

Proses analisis data yang dilakukan dalam penelitian ini didasarkan pada prosedur analisis data yang dikemukakan oleh Miles dan Huberman, dalam Sugiyono dengan model pendekatan yang terdiri dari langkah- langkah sebagai berikut yaitu 1) data reduction (reduksi data), 2) data display (penyajian data), 3) conclution drawing/verification (penerikan kesimpulan /verifikasi). ${ }^{7}$

\section{PEMBAHASAN}

Penyajian data dalam penelitian ini diperoleh peneliti melalui proses pengambilan data dengan mengintervieu para mahasiswa, dosen dan Ka. Prodi yang terdapat di Fakultas Agama Islam Universitas Muhammadiyah Gresik. Berdasarkan proses pengambilan data di lapangan yang mengedepankan pendekatan snow ball atau pendekatan bola salju, maka proses 
pengambilan data tersebut menghasilkan data yang dapat disajikan sebagai berikut ini.

Berikut ini disajikan hasil wawancara dengan Ka. Prodi Pendidikan Agama Islam mengenai pembelajaran Pendidikan Pancasila dikaitkan dengan pembinaan karakter mahasiswa di Fakultas Agama Islam Unmuh Gresik. Menurut ibu Muyasaroh, M.Pd.I. bahwa:

Secara komprehensif pendidikan itu adalah upaya penyadaran manusia mengenai hakekat kemanusiaannya itu sendiri. Oleh karena itu manusia handaknya secara sadar dan terencana memprogram dan melaksanakan proses pendidikan, terutama pendidikan nilai seperti Pendidikan Pancasila yang bersentuhan langsung dengan pembentukan karakter manusia, sehingga dalam rangka memanusiakan dirinya manusia Indonesia tidak dapat dipisahkan dari nilai yang terkandung dalam pendidikan Pancasila, baik sebagai pribadi, warga masyarakat dan sekaligus sebagai warga bangsa dan Negara, bahkan sekaligus sebagai warga dunia, jika dikaitkan dengan ide dan isu dalam konteks global di era globalisasi dewasa ini. (Wawancara, 26 Mei 2017)

Berkaitan dengan pembelajaran Pendidikan Pancasila sebagai mata kuliah pengembangan kepribadian inplementasinya di Prodi Pendidikan Agama Islam khususnya dan Fakultas Agama Islam secara umum, Menurut Ibu Muyasaroh bahwa:

Pembelajaran Pendidikan Pancasila yang diberi bobot 2 sks telah menjadi bagian integral dari kurikulum KKNI yang diterapkan di tingkat Fakultas Agama Islam dan juga sudah menjadi kebijakan di level Universitas Muhammadiyah Gresik. Jadi pembelajaran Pendidikan Pancasila senantiasa dilaksanakan mengikuti pola kebijakan
Kementrian Riset Dikti, sehingga pembelajarannya diharapkan mampu memberikan hasil maksimal dalam membentuk karakter lulusan yang selaras dengan tujuan pembe-lajaran Pendidikan Pancasila, serta memenuhi kriteria dari tujuan pendi-dikan nasional. Walaupun masih ada kendala yang terjadi dalam proses pembelajaran mata kuliah Pendidikan Pancasila, karena keterbatasan jumlah jam kuliah dan bobot sks yang hanya 2 sks dengan materi bahan ajar yang sangat banyak dan beragam. (Wawancara, 26 Mei 2017)

Berkaitan dengan keberadaan pembelajaran mata kuliah Pendidikan Pancasila di Fakultas Agama Islam dalam kaitannya dengan animo mahasiswa untuk menekuni materi Pendidikan Pancasila, Menurut penilaian ibu Ka. Prodi Pendidikan Agama Islam, beliau menjelaskan bahwa:

Kesadaran belajar mahasiswa di fakultas ini memiliki animo yang tergolong tinggi, terbukti dimana mayoritas mahasiswa Fakultas Agama Islam merupakan mahasiswa yang kuliah sambil bekerja dan bekerja sambil kuliah. Kondisi seperti ini membutuhkan energy kehidupan yang ekstra besar untuk menempuh dua aktivetas kerja dan kuliah secara berbarengan. Sehingga apabila maha-siswa tidak memiliki komitmen diri yang kuat sudah barang tentu mereka tidak akan berjuang sedemikian hebatnya untuk mewujudkan cita-citanya. Berdasarkan kondisi sebagai-mana digambarkan dapatlah dikemu-kakan mahasiswa memiliki animo untuk secara serius mempelajari semua materi kuliah termasuk mata kuliah Pendidikan Pancasila. (Wawancara, 26 Mei 2017) 
Karakter sebagai sesuatu fenomena yang sedang diupayakan pembinaannya dalam membangun kepribadian bangsa secara komprehensif, mulai dari diri individu, keluarga, masyarakat hingga tatanan kehidupan bernegara, kini menjadi bagian integral bagi dunia pendidikan, termasuk dunia pendidikan tinggi dalam mendidik mahasiswa. Bagaimana pandangan ibu berkaitan dengan pembinaan karakter terhadap mahasiswa di Fakultas Agama Islam Unmuh Gresik ini? Berkaitan pertanyaan tersebut dikemukan bahwa:

Karakter merupakan refleksi diri manusia secara sistematis berkenaan dengan kesadaran manusia untuk menginternalisasi semua sistem nilai yang diperolehnya dalam hidup dan kehidupannya, baik itu melalui proses pembelajaran secara formal maupun secara non formal, juga berkanaan dengan keberadaan nilai-nilai kehidupan yang didapatkan dari pengalaman hidup yang riil. Kemudian sistem nilai tersebut diolah dalam sistem pemikiran intelektual, emosional dan spiritualnya lalu diwujudkan dan diaplikasikan sebagai pola hidupnya secara konsisten, maka hal tersebut dalam arti sistem nilai tersebut akan manjadi karakter diri sebagai manusia. Oleh karena itu manusia termasuk mahasiswa sebagai person pembelajar hendaknya mampu memahami dan mengembangkan diri berdasarkan sistem nilai yang yang diperoleh dari proses pembelajaran guna membangun dan membina kerakter dirinya secara kontinu. (Wawancara, 26 Mei 2017)

Sebagaimana dikemukakan bahwa pengertian karakter tidak bisa dipisahkan dari keberadaan sistem nilai yang terintegrasi dalam diri dan kehidupan manusia, dimana manusia yang hidup dibentuk oleh sistem nilai yang melingkupinya. Berkaitan dengan sistem nilai yang dibutuhkan manusia dalam pembinaan karakter dirinya, dan sudah dimaklumi bahwa Pendidikan Pancasila yang diselenggarakan oleh semua dunia pendidikan tinggi di Indonesia sebagai usaha membina karakter mahasiswa agar berkepribadian Indonesia yang berPancasila, Dalam konteks ini menurut ibu Muyasaroh, bagaimana peran dari Pendidikan Pancasila berhubungan dengan pembinaan karakter mahasiswa di Fakultas Agama Islam Unmuh Gresik ini? Merespon pertanyaan ini beliau berpendapat bahwa:

Pendidikan Pancasila di perguruan tinggi termasuk fakultas Agama Islam UMG ini adalah upaya secara sadar, terencana, sistematik dan terstuktur untuk menanamkan nilai-nilai Pancasila kedalam diri setiap mahasiswa, agar mereka memiliki pengertian yang benar tentang Pancasila sebagai dasar filosofi dan ideologi negara Republik Indonesia, kemudian mahasiswa menjadikan nilai Pancasila sebagai sistem nilai dalam membentuk pola pikir, pola sikap dan pola perilaku, serta mengaplikasikan nilai Pancasila tersebut untuk membina diri dalam kehidupan berpribadi, bermasyarakat dan bernegara secara harmonis. Walaupun demikian perlu disadari bahwa dalam kehidupan ini manusia termasuk mahasiswa senan-tiasa berinteraksi dengan berbagai sistem nilai, baik itu nilai yang positif maupun nilai yang negatif. Oleh karena itu, berkaitan dengan pembinaan karakter, dibutuhkan adanya satu sistem nilai yang bersifat fundamental sebagai filter penyaring terhadap nilai-nilai yang ditemuinya dalam hidup dan kehidupannya. (Wawancara, 26 Mei 2017) 
Nilai fundamental sesungguhnya adalah sistem nilai yang sangat penting bagi diri manusia secara komprehensif, karena nilai tersebut akan menjadi dasar kepribadian atau karakter manusia dalam menghadapi dirinya, masyarakatnya dan bangsanya daalam hidup dan kehidupan bernegara. Nilai Pancasila yang disosialisasikan melalui mata kuliah Pendidikan Pancasila adalah perwujudan kehendak kebijakan negara untuk membangun sistem nilai fundamental sebagai nilai dasar yang harus dipahami dan diamalkan dalam kehidupan berpribadi, bermasyarakat, berbangsa dan bernegara sebagai refleksi karakter manusia Indonesia seutuhnya. Berkaitan dengan gambaran dimaksud bagaimana pandangan ibu Ka. Prodi Pendidikan Agama Islam mengenai keberadaan Pendidikan Pancasila sebagai perwujudan pembentukan dan terutama pembinaan karakter mahasiswa fakultas Agama Islam Unmuh Gresik?

Menyikapi pertanyaan ini, beliau berpendapat bahwa:

Perlu disadari dan dimaklumi bahwa realita bangsa Indonesia adalah bangsa yang bersifat kebhinekaan atau bangsa yang bersifat plural. Corak kehidupan bangsa Indonesia yang beraneka ragam ini tidak dapat dipisahkan dari sistem nilai funda-mental yang diyakini dan dijadikan sebagai prinsip hidup dan kehidupan mereka. Begitulah kiranya keberadaan manusia sebagai makhluk multi dimensional, dimana manusia karakternya tidak hanya diberntuk oleh satu sistem nilai semata, tetapi dibentuk oleh beraneka ragam nilai yang diterimanya, disamping nilai fundamental yang diyakininya. Oleh karena itu, perlu dimaklumi bahwa Masyarakat kita terutama para mahasiswa sebagai kaum terpelajar, mereka pasti akan berinteraksi dengan berbagai sistem nilai sebagai upaya pengayaan diri. Contohnya mahasiswa yang beragama Islam sudah barang tentu mereka tidak dapat melepaskan diri dari ajaran agamanya, demikian seterusnya bagi mereka non muslim. Oleh karena itu, dalam kaitannya dengan pembinaan karakter mahasiswa, perlu dilakukan secara bijak dengan tidak memben-turkan atnara satu sistem nilai dengan yang lainnya. Selama sistem nilai tersebut memiliki relevansi yang kuat. Misalnya membentukan nila Islam dengan Nilai Pancasila, yang secara filosofi dan historis Islam sebagai agama samawi termasuk azas terpenting dalam merumuskan dan melahirkan nilai Pancasila sebagai dasar negara. Itulah sebabnya dalam pembelajaran

Pendidikan Pancasila senantiasa disinergikan dengan nilai Islam agar tidak terjadi disorientasi nilai dan makna dari kedua sistem nilai yang merupakan sistem nilai yang saling berkaitan bagi manusia Indonesia, khususnya mahasiswa fakultas Agama Islam dalam pembinaan karakternya, sehingga tunmbuh menjadi manusia Indonesia seutuhnya dan terbebas dari fitnah radikalisme yang diisukan manusia laknatullah yang tak bertanggungjawab. (Wawancara, 26 Mei 2017).

Berkenaan upaya memperoleh data secara lebih komprehensif, informan selanjutnya yang direkomendasikan Ka. Prodi PAI dalam kaitan penelitian ini adalah dosen senior bapak Dr. H. Aslich Maulana, SH., M.Ag. Berkaitan dengan kondisi pembelajaran Pendidikan Pancasila bagi mahasiswa beliau berpendapat bahwa:

"Proses pembelajaran semua mata kuliah termasuk mata kuliah Pendidikan Pancasila di Prodi PAI sudah berlangsung sesuai ketentuan yang berlaku menurut kurikulum KKNI yang 
mulai diterapkan sejak tahun 2014. Jadi insyaAllah proses pembelajaran dengan sistem sks dengan jumlah pertemuan 16 selama satu semester tidak terabaikan." (Wawancara, 27 Mei 2017)

Sebagaimana dimaklumi bahwa Pendidikan Pancasila sebagai salah satu mata kuliah yang termasuk dalam rumpun mata kuliah pengembangan kepribadian disamping mata kuliah Pendidikan Agama (Islam) dan pendidikan Bahasa Indonesia. Oleh karena itu, Pendidikan Pancasila mempunyai keterikatan erat dengan persoalan pembinaan karakter mahasiswa sebagai pembelajar. Bagaimana pendapat bapak Aslich Maulana terntang keterkaitan Pendidikan Pancasila dengan pembinaan karakter mahasiswa dimaksud? Menikapi pertanyaan dimaksud beliau berpendapat bahwa:

"Pendidikan Pancasila pada dasarnya mengajari mahasiswa mengenai nilainilai ideologi bangsa Indonesia yang merupakan dasar falsafah bangsa. Nilai ideologi adalah nilai yang tidak sekedar diketahui, tetapi harus terinter-nalisasi secara komprehensif dan membentuk kepribadian setiap manusia Indonesia termasuk mahasiswa Fakultas Agama Islam. Dalam konteks ini maka secara otomatis nilai ideologi termasuk ideologi Pancasila akan menjadi jalan hidup manusia Indonesia dalam berbangsas dan bernegara, dan secara langsung teraktualisasi sebagai karakter diri setiap warga negara Indonesia, termasuk mahasiswa. Namun perlu disadari bahwa ideologi yang hidup dan berkembang dalam suatu komunitas bangsa termasuk bangsa Indonesia

bersifat pluralistik dan multi-dimensional. Jadi di Indonesia yang berideologi Pancasila terdapat pula ideologi lainnya seperti ideologi Komenis, Liberalisme dan juga ideologi yang berbasik Agama, misalnya Islam, Kristen dan lainnya.(Wawancara, 27 Mei 2017)

Berkaitan dengan keberadaan ideologi Pancasila di tengah-tengah percaturan ideologi yang hidup di masyarakat Indonesia sejak era penjajahan hingga kita merdeka sebagai bangsa dewasa ini, kontribusi ideologi yang hidup di masyarakat terutama ajaran agama Islam apakah mempunyai kontribusi dalam pembelajaran Pendidikan Pancasila dalam kaitannya dengan pembinaan karakter mahasiswa Fakultas Agama Islam UMG? Menanggapi pertanyaan ini ustadz Aslich Maulana berpendapat bahwa:

"Keberadaan Pancasila sebagai dasar negara, ideologi negara dan filsafat serta pandangan hidup maupun sebagai jiwa bangsa tidak dapat dipisahkan dari nilai-nilai agama terutama agama Islam. Sebagaimana dimaklumi bahwa pada saat perumusan nilai Pancasila keterlibatan tokoh-tokoh muslim sangat dominan dan menentukan proses perumusan dasar negara Pancasila tersebut. Oleh karena itu, maka pembelajaran Pendidikan Pancasila tidak bisa dipisahkan dari nilai ajaran agama, khususnya ajaran agama Islam.

Lebih lanjut ustadz Aslich Maulana mengemukakan ilustrasi terhadap urgensinya ajaran agama Islam dalam mekanisme berPancasila bahwa:

"Sebagai contoh, mustahil mahasiswa bisa memahami makna substansial dari Sila pertama "Ketuhanan Yang Maha Esa" tampa memiliki pemahaman yang komprehensif terhadap ajaran agamanya. Demikian pula pemahaman terhadap sila kedua Kemanusiaan yang adil dan beradab, 
sila ketiga, Persatuan Indonesia, sila keempat, Kerakyatan yang dipimpin oleh hikmah kebijaksanaan dalam permusyawaratan/ perwakilan dan sila kelima Keadilan sosial bagi seluruh rakyat Indonesia. Dimana semuanya merupakan satu sistem, dimana sila pertama meliputi dan menjiwai sila-sila di bawahnya, sebaliknya sila-sila di bawahnya diliputi dan dijiwai sila pertama. Sehingga pembinaan karakter manusia Indonesia melalui Pendidikan Pancasila membutuhkan kolaborasi dimensi nilai yang ada dalam ajaran Agama, dalam hal ini ajaran agama

Islam untuk mahasiswa FAI." (Wawancara, 27 Mei 2017)

Penyajian data berikutnya adalah diperoleh dari hasil interview dengan bapak Noor Amirudin, M.Pd.I. sebagai dosen di Program Studi Pendidikan Agama Islam Fakultas Agama Islam Universitas Muham-madiyah Gresik. Adapun hasil wawancara-nya adalah sebagai berikut. Berkaitan dengan mata kuliah Pendidikan Pancasila yang merupakan matakuliah pembinaan kepribadian bagi mahasiswa di Fakultas Agama Islam Unmuh Gresik, sebagai dosen, bagaimana implementasi pembelajarannya dalam kaitannya dengan proses pembinaan karakter mahasiswa yang ada di fakultas ini? Menanggapi pertanyaan tersebut, ustadz Amir menuturkan bahwa:

Pembelajaran setiap matakuliah di fakultas Agama Islam termasuk mata kuliah Pendidikan Pancasila, secara spesifik meru-pakan usaha pembinaan dan sekaligus pengembangan karakter dan/atau kepri-badian mahasiswa untuk menjadi manusia utama istilah kami di Muhammadiyah atau secara umum dikenal dengan insan kamil. Oleh karena itu bagi setiap dosen fakultas Agama Islam, pembelajaran bukanlah sekedar transformasi ilmu pengetahuan, tetapi yang terpenting bagi kami pembelajaran itu lebih utama adalah proses internalisasi nilai (value) ke dalam diri pribadi mahasiswa kami, Terutama dalam pembelajaran Pendidikan Pancasila dan sejenisnya, seperti pendidikan agama Islam dan Kemuhammadiyahan, proses yang diselenggarakan sangat berfokus pada usaha menginternalisasikan sistem nilai pada diri mahasiswa agar mereka tidak sekedar mengetahui, tetapi mereka akan memahami dan membentuk kesadaran diri akan makna ilmu tersebut secara komprehensif. (Wawancara, 28 Mei 2017)

Mengenai implementasi pembelajaran pendidikan Pancasila di Fakultas Agama Islam menurut hematnya ustadz Noor Amirudin bahwa:

pembelajaran mata kuliah Pendidikan Pancasila diselenggarakan menurut ketentuan yang berdasarkan pedoman akademik yang disusun

berdasarkan ketentuan peraturan pemerintah dalam bidang pendidikan tinggi. Dimana untuk mata kuliah Pendidikan Pancasila dengan bobot 2 sks, dilaksanakan dengan durasi waktu 1 sks 50 menit, sehingga mata kuliah Pendidikan Pancasila dengan bobot 2 sks waktu kuliahnya menghabiskan waktu sekitar 100 menit. Kondisi dan ketentuan perkuliahan ini diberlakukan sama juga untuk semua mata kuliah yang terdapat dalam kurikulum Fakultas Agama Islam khususnya dan pada semua fakultas di Unmuh Gresik umumnya. (Wawancara, 28 Mei 2017)

Pembelajaran Pendidikan Pancasila sebagai mata kuliah yang berkaitan dengan penanaman nilai dasar negara dan nilai ideologi bangsa Indonesia kepada mahasiswa sebagai calon pemimpin bangsa 
Indonesia di masa yang akan datang, apakah sudah cukup memadahi bagi diri mahasiswa Fakultas Agama Islam? Menanggapi pertanyaan tersebut ustadz Noor Amirudin mengemukakan bahwa:

Pada prinsipnya pendidikan nilai kebangsaan sebagai upaya transformasi nilai luhur suatu bangsa dari generasi ke generasi berikutnya harus berlangsung secara terus menerus dan proses transformasi nilai harus pula memberikan jaminan bahwa generasi penerus mampu memahami makna nilai yang diwariskan sesuai pemahaman generasi pendahulunya. Sebab apabila terjadi ketidak samaan pemahaman terhadap nilai yang disampaikan, otomatis akan terjadi disorientasi makna dari nilai tersebut. Kondisi ini berakibat pada terjadinya perbedaan persepsi diantara generasi, bila ini terjadi akan berakibat krisis nilai yang dapat menimbulkan konflik antara generasi tua dan generasi penerusnya. Oleh karena itu pendidikan sebagai upaya pewarisan nilai budaya bangsa proses pembelajarannya berorientasi pada upaya internalisasi nilai Pancasila dan bukan hanya sekedar pembelajaran yang bersifat transformasi pengetahuan belaka. (Wawancara, $28 \mathrm{Mei}$ 2017)

Menyangkut kedudukan Pendidikan Pancasila dalam pembinaan karakter mahasiswa, ustadz Noor Amirudin berpendapat bahwa

Sebagaimana dimaklumi proses pendidikan yang berkaitan dengan internalisasi nilai berkaitan erat dengan proses pembentukan karakter bagi manusia yang tergolong berusia anakanak hingga usia remaja, sedangkan bagi manusia yang berusia dewasa awal atau remaja akhir, maka pendidikan lebih merupakan proses pembinaan karakter ke arah kedewasaan diri secara komprehensif. Oleh sebab itu, maka sudah selayaknya Pembelajaran Pendidikan Pancasila tidak sekedar mengajari mahasiswa tentang segenggam asumsi-asumsi kosong mengenai ilmu pengetahuan, tetapi hendaknya menanamkan nilai yang bermuatan makna kehidupan sesunngguhnya bagi mahasiswa agar mereka menjadi manusia siap hidup layak secara manusiawi dan begitulah seharusnya Pendidikan Pancasila sebagai pembinaan karakter. (Wawancara, 28 Mei 2017)

Nilai Pancasila dirumuskan para pendiri bangsa Indonesia tidak hanya sebagai dasar negara, melainkan juga sebagai jiwa dan kepribadian masyarakat dan bangsa serta seluruh masyarakat Indonesia. Konsekuensinya maka Pancasila harus diaplikasikan oleh seluruh rakyat Indonesia. Oleh sebab itu, sebagai warga bangsa Indonesia kita wajib memahami, menghayati dan mengamalkan nilai-nilai Pancasila dalam kehidupan kita sebagai komunitas bangsa Indonesia sebagai wujud kebutuhan atas sistem nilai keadaban kita yang mencintai negeri ini. Bagaimana pendapat ustadz Amirudin terhadap kondisi penghayatan dan pengamalan nilai Pancasila dalam kaitanya dengan pembinaan karakter mahasiswa fakultas agama Islam Unmuh Gresik? Merespon pertanyaan dimaksud menurut ustadz Noor Amirudin bahwa:

Hakekat mahasiswa sebagai manusia secara universal itu oleh Allah Sang Maha Pencipsi dibekali dengan dua potensi kejiwaan pada jiwa yakni potensi fujur atau ingkar dan taqwa atau patuh dan taat kepada Allah Tuhan yang maha Kuasa. Konsekuensi logis dari ihwal manusia dalam penciptaannya terseut bisa mengakibatkan manusia menjadi berkarakter ingkat pada dirinya dan sebaliknya manusia menjadikan dirinya sebagai hamba yang bertaqwa pada Allah sebagai wujud kesadaran 
kemanusiaan manusianya yang adalah mahluk. Oleh karena itu, sudah seharusnya manusia dalam membina dirinya tidak boleh terputus baik secara habluminallah maupunn habluminanas, hal ini sebagai cara termudah dalam membina karakter dirinya, ketentuan ini sebagaimana dimaklumi bahwa dalam membina karakter diri ini manusia tidak dapat melepaskan diri dari hidayah Allah dan juga dengan jalinan sosial sebagai wadah bagi setiap manusia untuk mengaktualisasi diri dalam menjalani fase demi fase kehidupannya. ( Wawancara, 28 Mei 2017)

Apabila ditelaah lebih mendalam dapat diasumsikan bahwa pembinaan karakter mahasiswa sebagai manusia tidak dapat dipisahkan antara nilai yang dihasilkan oleh pemikiran manusia dengan nilai agama dalam konteks ini agama Islam yang dianugrahkan Allah Ta'ala kepada manusia berkaitan upaya manusia membangun kepribadian atau karakter dirinya. Bagaimana substansi dari aktualisasi diri mahasiswa fakultas agama Islam Unmuh Gresik dalam pengaplikasian nilai nilai Pancasila dalam pembinaan karakter mereka? Menanggapi persoalan ini ustadz Noor Amirudin mengemukakan bahwa:

Berkaitan dengan pembinaan karakter mahasiswa dalam relevansinya dengan pengamalan nilai Pancasila sebagai kepribadian bangsa, sesungguhnya Menurut hemat saya, dimana nilai Pancasila tersebut hakekatnya merupakan system nilai yang bersumber atau berasal dari ajaran agama Islam. Oleh karena itu, pada hakekatnya apabila mahasiswa yang beragama Islam telah menjadikan nilai Islam sebagai tatanan nilai kehidupannya, dalam arti telah konsisten beribadah sesuai dan Menurut ketentuan Islam sebagai agamanya, Dimana nilai Islam telah membentuk karakter atau kepribadiaannya, maka secara otomatis nilai Ketuhanan Yang Maha Esea telah menjadi dasar kepribadiaannya, dimana nilai sila pertama Pancasila sebagaimana dikemukan para pakar bahwa sila Ketuhanan Yang Maha Esa meliputi dan menjiwai sila yang ada dibawahnya dan sila dibawahnya diliputi dan dijiwai oleh yang diatasnya yakni sila Ketuhanan Yang Maha Esa. Dimana sila Ketuhanan Yang Maha Esa, sebagai representasi keberagamaan bangsa dan rakyat Indonesia. Maka keberadaan mahasiswa yang demikian dapat ditegaskan merupakan hasil atau keberhasilan Pendidikan Pancasila dalam pembinaan karakter mahasiswa termasuk mahasiswa Fakultas Agama Islam Unmuh Gresik. .(Wawancara, 28 Mei 2017)

Selanjutnya akan disajikan data dari hasil wawancara dengan beberapa responden dari tokoh mahasiswa Fakultas Agama Islam Unmuh Gresik, guna mendapatkan data dan informasi terkait dengan pembinaan karakter mahasiswa. Adapun proses interview berikut ini dilakukan dengan saudara Choiri Sulaiman, berkenaan dengan keberadaan pembelajaran Pendidikan Pancasila di Fakultas Agama Islam Unmuh Gresik. Menanggapi hal tersebut dikemukakan bahwa:

Pembelajaran Pendidikan Pancasila di Fakultas Agama Islam telah terselenggarakan dengan baik dan tidak ada kesulitan bagi mahasiswa dalam memahami dan memaknai hakekat dari nilai Pancasila. Sebagai mahasiswa kami menilai bahwa pembelajaran Pendidikan Pancasila telah dirasakan sebagai proses internalisasi nilai kepribadian bangsa kepada generasi penerus. Dimana generasi penerus harus memahami dan menghayati serta 
mengamalkan nilai tersebut secara konsisten dalam menjalani hidup dan kehidupannya agar tidak mengalami krisis kepribadiannya sebagai anak bangsa Indonesia yang Pancasilais. (Wawancara, 4 Juni 2017)

Bagaimana padangan saudara berkaitan dengan proses pembelajaran Pendidikan Pancasila dengan pembinaan karakter bagi mahasiswa fakultas Agama Islam Unmuh Gresik? Berkaitan dengan pertanyaan dimaksud Menurut mas Sulaiman bahwa:

Secara kasat mata atau secara riil pembelajaran Pendidikan Pancasila telah memberikan makna yang berkaitan dengan nilai-nilai ketuhanan, kemanusiaan, kebangsaan, kerakyatan atau demokrasi serta keadilan sosial. Nilai nilai ini sebenarnya merupakan system nilai yang bersifat universal, yang penting bagaimana nilai tersebut diterjemahkan ke dalam kepribadian bangsa Indonesia agar sesuai karakter kebangsaan Indonesia. Proses pengIndonesiaan terhadap nilai Pancasila yang sangat bermakna universal ini, membutuhkan ketauladanan dan contoh nyata dari para pemimpin bangsa secara bertanggungjawab secara moral kepada generasi penerusnya secara konsisten. (Wawancara, 4 Juni 2017)

Berkaitan dengan ungkapan dari mas Sulaiman yang berkaitan dengan persoalan bahwa pembinaan karakter tidaklah sekedar transformasi pengetahuan dan nilai normatif yang terdapat dalam rumusan Pancasila, melainkan lebih membutuhkan keteladanan. Bagaimana pendandapat saudara berkaitan dengan refleksi nilai normatif Pancasila dalam kehidupan riil bangsa Indonesia dewasa ini? Berkenaan dengan pertanyaan tersebut, mas Sulaiman berargumentasi bahwa:

Pendidikan dan pembelajaran itu bukanlah suatu proses di alam mimpi belaka, tetapi proses pendidikan haruslah menjadi suatu aktivitas yang hadir dalam kehidupan nyata baik pada diri pengajar atau dosen maupun pada diri mahasiswa yang dididik. Apalagi berkaitan dengan pembelajaran mata kuliah seperti Pendidikan Pancasila yang menyangkut pembinaan jiwa generasi mada agar memiliki jiwa dan kepribadian serta berkarakter Pancasilais, maka mau tidak mau pendidikan harus bersifat aplikatif dalam mengembangkan nilai kepribadian mahasiswa sebagai peserta didik mem-butuhkan keteladanan agar mereka tidak tersesat dan terjebak radikalisme ideologi sebagaimana yang marak terjadi dewasa ini. Tanpa keteladanan proses pendidikan karakter akan berlangsung hambar dan akan gagal dalam membangun karakter diri anak bangsa Indonesia. (Wawancara, 4 Juni 2017)

Berdasarkan pendapat tersebut, lebih lanjut bagaimana menurut saudara keberadaan Pendidikan Pancasila dalam kaitannya dengan pembinaan karakter mahasiswa Fakultas Agama Islam? Menanggapi pertanyaan dimaksud mas Choiri Sulaiman berasumsi bahwa:

Secara teoritis dan dalam proses interaksi akademis ilmu pengetahuan yang dipelajari mahasiswa mampu membangun paradigm berpikir secara positif dan konstruktif, namun perlu disadari bersama bahwa ilmu itu bukanlah sekedar untuk ilmu, tetapi ilmu itu adalah modal dasar bagi manusia untuk menjalani kehidupan. Untuk mempraktek ilmu terutama ilmu yang bersifat fundamental seperti Pendidikan Pancasila, karena menyangkut penegakan harkat dan martabat diri 
bangsa Indonesia, sungguh tidak ada maknanya apabila ilmu mengajarkan kebenaran sementara perilaku kita sebagai bangsa menyelisihi nilai kebenaran tersebut. Misalnya Pancasila mengajarkan kita untu mengesakan Tuhan sementara kita berbuat siriq, demikian pula kita diajarkan untuk berkemanusiaan yang adil dan beradab, sementara perilaku kita berbanding terbalik dengan memperagakan perangai yang tidak adil dan biadab. (Wawancara, 4 Juni 2017)

Guna melengkapi data penelitian ini agar lebih komprehensif, berikut ini dilanjutkan wawancara dengan Dewi Syahidah yang berkaitan dengan kondisi pembelajaran pendidikan Pancasila. Menanggapi pertanyaan tersebut dikemukakan bahwa:

\begin{abstract}
"Pembelajaran Pendidikan Pancasila sudah dilaksanakan sesuai ketentuan kurikum yang ada, sehingga tidak ada kesulitan yang terjadi dalam proses pembelajarannya. Oleh karena itu diharapkan agar mahasiswa dan dosen konsisten menerapkan amanah kurikulum, jadi hanya dengan semangat disiplin semua pihak maka pembelajaran akan berhasil sesuai rencana."

.(Wawancara, 4 Juni 2017)
\end{abstract}

Keberadaan pembelajaran mata kuliah Pendidikan Pancasila sebagaimana dikemukakan responden secara konseptual telah diaplikasikan sesuai ketentuan pembelajaran. Lebih lanjut berkaitan dengan implementasi nilai-nilai Pancasila dalam kaitannya dengan pembinaan karakter mahasiswa, responden berpendapat bahwa:

"Dalam proses pembelajaran sudah disampaikan secara komprehensif nilainilai Pancasila kepada mahasiswa, namun persoalannya tidak sesederhana itu, mengingat bahwa kebenaran nilai Pancasila tidak sekedar hadir dalam layar persepsi mahasiswa belaka, sebagaimana yang diajarkan. Bagi kami sebagai mahasiswa hal terpenting adalah hadirnya figur pemimpin secara nasional atau minimal secara lokal maupun regional yang dapat dijadikan teladan untuk dicontohi para mahasiswa. Dewasa ini figur teladan tersebut sangat nihil jaka tidak dikatan tak ada lagi di masyarakat kita.” (Wawancara, 4 Juni 2017)

Apabila saudari Dewi Syahidah beranggapan bahwa permasalahan pembinaan karakter mahasiswa tidak sekedan mengajarkan melalui perkuliahan saja, namun dibutuhkan adanya figur pemimpin tang dapat diteladani. Menurut saudari apakah krisis keteladanan berdampak dalam kaitannya dengan peran pendidikan Pancasila dalam pembinaan karakter mahasiswa?

"Secara realistis menurut saya Pendidikan Pancasila sebagai upaya menanamkan nilai-nilai luhur bangsa Indonesia kepada mahasiswa sebagai calon pemimpin bangsa di masa yang akan datang mempunya posisi dan fungsi strategis. Karena melalui pendidikan Pancasila inilah mahasiswa akan mengenal dan memahami nilai-nilai kepribadian bangsanya dan sekaligus nilai tersebut akan dijadikan pijakan dalam membangun dan mem-bina karakter dirinya sebagai generasi bangsa yang berkualitas. Dan itu berarti menurut hemat saya Pendidikan Panca-sila mempunyai peran cukup signifikan dalam pembinaan karakter, Walaupun demikian patut disadari juga mahasiswa sebagai pembelajar senantiasa me-nyerap nilai kebenaran tidak hanya terbatas pada Pancasila, tetapi masih terdapat nilai yang lain di antaranya 
agama dan nilai budaya leluhur yang saling menguatkan dalam pembinaan karakter dirinya." (Wawancara, 4 Juni 2017)

Sebagaimana saudari Dewi Syahidah kemukakan bahwa Pendidikan Pancasila mempunyai peran signifikan dalam pembinaan karakter mahasiswa di Fakultas Agama Islam UMG. Lebih lanjut dikemukakan pula bahwa nilai agama dan budaya ikut berperan dalam pembinaan karakter mahasiswa. Menurut saudara dimana letak peran agama dan budaya dalam berkontribusi dalam membina karakter mahasiswa di negara Indonesia yang berdasarkan Pancasila?

"Menurut hemat saya dalam pembelajaran Pendidikan Pancasila, terdapat konsep teori yang mengemukakan bahwa nilai Pancasila bersumber dari nilai agama. Nilai kebudayaan dan nilai moral serta nilai etika yang digali dari nilai luhur bangsa Indonesia. Sehingga dapat dijelaskan bahwa antara agama dan budaya bangsa Indonesia dan nilai Pancasila terdapat korelasi signifikan, sehingga tidak dapat dpiisahkan. Bahkan pada hematnya nilai sila pertama Pancasila "Ketuhanan Yang Maha Esa" bersumber dari ajaran agama Islam. Sehingga sungguh tidak dapat dibenarkan jika dikatakan antara Islam dan Pancasila tak ada kaitannya, seperti yang ramai diperbincangkan saat ini." (Wawancara, 4 Juni 2017)

Dari penjabaran saudari Dewi Syahidah tersebut, dimana nilai Pancasila yang diajarkan dalam Pendidikan Pancasila, terdapat saling keterkaitan antara Agama, Kebudayaan bangsa Indonesia dengan nilai Pancasila, sehingga berkaitan dengan pembinaan karakter mahasiswa tidak dapat dipisahkan satu dengan lainnya diantara nilai tersebut? Menyikapi hal tersebut dikemukakan bahwa:

"Hakekat nilai itu bersifat sistematis, dimana adanya saling keterkaitan antara satu dengan lainnya. Oleh karena itu, antara Agama, kebudayaan dan nilai moralitas bangsa, akan terkristalisasi dan berkolaborasi serta dirumuskan menjadi nilai-nilai Pancasila. Sehingga secara hakiki akan membentuk nilai kebangsaan Indonesia yang terefkleksi membentuk karakter dirinya sebagai bangsa berkeadaban."

Melengkapi data yang sudah diperoleh dari proses wawancara dengan para responden tersebut, berikut ini dipaparkan hasil pengamatan atau observasi peneliti tentang peranan Pendidikan Pancasila dalam pembinaan karakter mahasiswa Fakultas Agama Islam Unmuh Gresik. Secara garis besar proses pembelajaran Pendidikan Pancasila yang dikelolah oleh Tim Dosen Pendidikan Pancasila telah berlangsung sesuai ketentuan dan kebijakan yang ditetapkan pempinan universitas. Khususnya di lingkungan fakultas agama Islam, pembelajaran Pendidikan Pancasila mengacu pada kurikulum KKNI, dan penerapannya senantiasa dikaitkan dengan pendekatan student centre learning. dimana pembelajaran berorientasi pada keaktifan mahasiswa. Pendekatan dimana mahasiswa menjadi pusat pembelajaran, diharapkan agar mahasiswa dalam memahami dan mengaplikasi ilmu dan nilai yang diinternalisasikan dan kemudia diaktualisasikan dalam realita kehidupannya secara adil dan beradab.

Mahasiswa fakutas agama Islam selama ini dikenal sebagai suatu komunitas ilmiah 
yang konsisten mengamalkan nilai ajaran Islam yang didalam terdapat ajaran untuk bertuhan yang maha esa, berlaku adil dan beradab hingga berkeadilan. Refleksi nilai keislaman seperti ini secara ekplisit merupan wujud dari aktualisasi nilai Pancasila dalam realitas kehidupannya. Oleh karena itu, tidak dapat diabaikan bahwa hakekat peran dari pembinaan karakter melalui Pendidikan Pancasila, sangat ditentukan dari terbangunnya kesadaran untuk menjadikan tradisi kehidupan beragama dalam kehidupan nyata di dunia sosial, sebagai wujud pembinaan karakter yang berorientasi pada nilai Pancasila.

\section{Analisa dan Interpretasi Data}

Pembelajaran Pendidikan Pancasila secara subtansial adalan proses internalisasi nilai kebangsaan Indonesia kepada generasi muda sebagaimana dikehendaki oleh para pendahulunya sebagai upaya melestarikan nilai-nilai luhur kepribadian bangsa Indonesia. Tujuannya adalah agar bangsa Indonesia tidak mengalami krisis nilai kebangsaan yang akan menjadi ancaman terhadap integrasi bangsa Indonesia. Pendidikan Pancasila dalam kehidupan berbangsa disepakati oleh para responden, bukan sebagai suatu proses pembelajaran yang berlangsung secara skeptis, namun pembelajaran Pendidikan Pancasila berlangsung dalam realita kehidupan yang sesungguhnya secara nyata dan sesungguhnya hidup dalam jiwa sebagai sumber inspirasi membangun bangsa. Perspektif ini menghendaki agar proses pembelajaran Pendidikan Pancasila senantiasa menyentuh persoalan yang berkaitan dengan komitmen mengaplikasikan nilai Pancasila dalam kehidupan nyata dengan dibuktikan adanya keteladanan dari kaum elite yang menjadi penguasa Negara kepada rakyatnya terutama mahasiswa sebagai calon pemimpin masa depan bangsa Indonesia.

Keteladanan Menurut para responden adalan wujud terpenting bagi suatu komunitas berbangsa dan bernegara dalam memberikan pembelajaran karakter bagi sesama manusia, kerana melalui proses keteladanan proses internalisasi dapat disaksikan secara langsung dengan mengimitasi dan mengidentifikasi nilai karakter dari sumbernya yang berkompeten. Pendidikan dan pembinaan karakter bila dapat dioptimalkan dengan ketauladanan bisa dapat memberikan dampak positif terhadap mahasiswa, dimana mereka akan meneladani langsung dan hal ini akan mencegah terjadinya diorientasi pemahaman nilai di kalangan mahasiswa.

Mahasiswa Fakultas Agama Islam yang secara langsung senantiasa bergelut dengan pembelajaran nilai-nilai kebenaran agama Islam, secara tersurat dan tersirat akan memberikan kemudahan pemahaman dalam mempelajari dan menginternalisasi nilai yang ada dalam Pendidikan Pancasila, karena secara substansial nilai yang terdapat dalam Pancasila bersumber dari ajaran agama terutama ajaran agama Islam. Oleh karena itu, maka tidak ada kontradiksi nilai antara ajaran Islam dengan nilai Pancasila apabila tidak dimaknai secara kontroversial. Dimana nilai yang diajarkan mata kuliah Pendidikan Pancasila hakekatnya berasal dari system nilai agama, kebudayaan dan nilai etika moralitas yang berlaku dan hidup dalam peradaban bangsa Indonesia secara berkesinambungan.

Pembinaan karakter mahasiswa Fakultas Agama Islam berdasarkan pendapat 
responden telah berlangsung secara benar sesuai dengan ketentuan yang berlaku, namun demikian dalam proses pembinaan karakter mahasiswa di fakultas agama Islam, terdapat saling keterkaitan antara berbagai disiplin ilmu yang diajarkan kepada maha-siswa. Pendidikan Pancasila, dan Pendidikan agama Islam dan Kemuhammadiyahan, dinilai mempunyai kontribusi strategis dalam pembinaan karakter mahasiswa, karena kedua rumpun ilmu pengetahuan ter-sebut, secara langsung bersentuhan dengan persoalan nilai dan proses internalisasinya dalam membentuk karakter manusia termasuk membentuk karakter mahasiswa fakultas agama Islam Unmuh Gresik.

Sampai sejauh ini jika diinterpretasikan bahwa Pendidikan Pancasila dalam kaitannya dengan pembinaan karakter mahasiswa di lingkungan fakultas agama Islam Universitas Muhammadiyah Gresik telah berlangsung secara efektif, dimana selama ini tidak terdapat adanya mahasiswa yang terkontaminansi nilai-nilai ideologi radikalisme yang bertentang dengan nilai-nilai Pancasila dan nilai etike serta moralitas bangsa dan Negara Indonesia. Kondisi dimana tidak adanya ideologi kontrovesi yang diyakini mahasiswa, mengingat dalam pembelajaran Pendidikan Pancasila dan pembelajaran Pendidikan Agama Islam dan Kemuhammadiyahan, senantiasa mengunakan pendekatan komparatif dan harmonis dalam menafsirkan nilai kebenaran yang terkandung dalam kedua rumpun ilmu dan nilai yang hakekatnya saling bersinergi.

\section{SIMPULAN}

1. Berkaitan dengan pembelajaran Pendidikan Pancasila di Fakultas Agama Islam Unmuh Gresik dapat disimpulkan bahwa proses pembelajaran yang ada telah berlangsung sesuai dengan ketentuan kurikulum KKNI, sehingga mahasiswa dalam mengikuti proses pembelajaran secara terencana dan pola pendekatan student centre learning telah dapat memberi ruang bagi mahasiswa dalam mengembangkan pola pembelajaran yang bersifat komunikatif, kritis, kreatif dan inovatif.

2. Berkaitan dengan kondisi karakter mahasiswa fakultas agama Islam Unmuh Gresik, dimana mahasiswa sebagai komunitas pencari kebenaran ilmu dan Islam senantiasa istiqomah membangun karakter diri berdasarkan nilai kepribadian bangsa Indonesia yang Pancasilais, namun tetap konsisten terdapat pengamalan ajaran agama Islam, yang diyakininya dan merupakan fondasi serta sumber dirumuskan prinsip Ketuhanan Yang Maha Esa sebagai kontribusi agama dalam membangun nilai Pancasila. Sehingga dalam pembinaan karakter mahasiswa fakultas agama Islam Unmuh Gresik, hubungan antara nilai agama dan nilai dasar Negara tidak menimbulkan ketidaksamaan persepsi dan tidak pula menimbulkan pola piker yang berorientasi radikalisme di kalangan mahasiswa FAI Unmuh Gresik.

3. Peranan Pendidikan Pancasila sebagai ilmu yang tidak sekedar 
melakukan tranformasi ilmu pengetahuan, melaikan lebih mengedepankan dan mengutamakan proses internalisasi nilai Ketuhanan, kemanusiaan, persatuan, kerakyatan dan keadilan sosial yang bersifat universal, kemunian diinterpretasikan dalam konteks keindonesiaan, menjadi faktor yang ikut menentukan keberhasilan pembinaan karakter mahasiswa fakultas agama Islam Unmuh Gresik. Namun demikian kesadaran akan relasi dalam ber-bagai disiplin ilmu serumpun yang yang berkaitan dengan pembelajaran dan pengkajian nilai, maka keberadaan dan peranan Pendidikan Pancasila yang berkolaborasi dengan pendidikan Agama Islam dan Kemuhammadiyahan, memberikan peran strategis dalam pembinaan
Karakter mahasiswa fakultas agama Islam Unmuh Gresik.

\section{Rekomendasi}

Fakultas Agama Islam dalam upaya pembinaan karakter mahasiswa hendaklah berorientasi pada pengembangan pende-katan yang bersifat kolaboratif, diantara berbagai bilang ilmu pengetahuan yang berkaitan langsung dengan pembinaan karakter mahasiswanya. Dengan pendekatan kolabhoratif, akan terbangun korelasi nilai dan makna nilai yang ada pada setiap bidang ilmu kedalam paradigm pemahaman yang bersifat komparatif. Pendekatan kolaboratif dalam pembinaan karakter akan meng-hasilkan proses pembelajaran yang efektif dan ini berkaitan erat mempermudah proses internalisasi nilai pada diri mahasiswa agar berlangsung secara harmonis. 
Man Arfa Ladamay - Pembelajaran Pendidikan Pancasila...

${ }^{1}$ M. Natsir dalam Hidayat Nuim, 2014, Agar Batu Bata Menjadi Rumah Yang Indah Esai-Esai Sosial Politik, Pustaka Al-Kautsar Jakarta, hal. 89

${ }^{2}$ Susilo Bambang Yudoyono dalam Muchlas Samani, Prof. Dr., \& Hariyanto, Drs. M.S., 2014, Konsep dan Model Pendidikan Karakter, Remaja Rosdakarya, Bandung, hal. 6

${ }^{3}$ Kementrian Komunikasi dan Informatika RI, Direktorat Jendral Informasi dan Komunikasi Publik, Topik Revolusi Mental, hal. 3 Revolusi mental pertama kali digunakan Presiden Soekarno tahun 1957 ketika revolusi nasional sedang berhenti. ...Semangat tersebut kini diimplementasikan sesuai kondisi nyata oleh Presiden Joko Widodo dengan tujuan lebih memperkokoh kedaulatan, meningkatkan daya saing dan mempererat persatuan bangsa.

${ }^{4}$ Mohammad Nuh, Ibid. hal. 8

${ }^{5}$ Nuim Hidayat, hal. 195. Menilai bahwa aktivis HTI (Hizbut Tahrir Indonesia) misalnya, bangga berlebihan terhadap kelompoknya dan 'hanya' menjadikan Taqiyuddin An-Nabhani sebagai rujukan utama pembinaannya. Begitu pula aktivis mahasiswa Ikhwanul Muslimin di Indonesia - yang sebagian besar menginduk pada Partai Keadilan Sejahtera. Mereka sudah merasa cukup bila sudah dibina dengan kitab-kitab dari Hasan Al-Banna atau tokoh Ikhwanul Muslimin lainnya. Pergerakan mahasiswa di Muhammadiyah (ikatan Mahasiswa Muhammadiyah) atau Nahdhatul Ulama (Pergerakan Mahasiswa Islam Indonesia) kurang lebih sama. Di PMII cenderung menjadikan Gus Dur sebagai rujukan utama dan sebagaian cenderung ke "Islam Liberal". Gerakan KH. Wachid Hasyim tidak menjadi inspirasi utama mahasiswa-mahasiswa PMII.

${ }^{6}$ Sugiyono, Metode Penelitian Pendidikan Pendekatan Kuantitatif, Kualitatif, dan R\&D, (Bandung, Alfabeta, 2008) hal. 15.

${ }^{7}$ Ibid., hlm. 337. 
Jurnal TAMADDUN - FAI UMG. Vol. XIX. No.1 / Januari 2018 